\title{
Arcrekonstrukciós és orthognath mütétek tervezési lehetőségei háromdimenziós képalkotói módszerekkel
}

\author{
Dobai Adrienn dr. ${ }^{1}$ - Markella Zsolt dr. ${ }^{2}$ \\ Vízkelety Tamás dr. ${ }^{3}$ - Barabás József dr. ${ }^{1}$ \\ ${ }^{1}$ Semmelweis Egyetem, Fogorvostudományi Kar, Arc-, Állcsont-, Szájsebészeti és Fogászati Klinika, Budapest \\ ${ }^{2}$ Óbudai Egyetem, Kandó Kálmán Villamosmérnöki Kar, Budapest \\ ${ }^{3}$ Dento-Cura Kft. magánrendelö, Budapest
}

\begin{abstract}
Munkánkban irodalmi adatok és néhány saját eset bemutatásán keresztül foglaljuk össze az orthognath és arcrekonstrukciós sebészet területén alkalmazható tervezési lehetőségeket, melyek a háromdimenziós (3D-) képalkotás megjelenésével váltak elérhetővé. Az arcrekonstrukciós és orthognath mútétek sokszor az egyetlen megoldást jelentik a fejlődési rendellenesség, trauma vagy tumor okozta arcdeformitások kezelésekor. Ezeknek a szakterületeknek nélkülözhetetlen eszköze a radiológiai képalkotás, mely nemcsak a diagnosztikában, hanem a kezelés megtervezésében is fontos szerepet játszik. A mútéti tervezések során korábban rutinszerüen használt oldalirányú teleröntgen-felvételeken végzett kétdimenziós analíziseket a cone-beam számítógépes tomográfia (CBCT) megjelenésével fokozatosan a három dimenzióban végezhető mérések váltották fel. Az analízisek adaptálásának első lépését a CBCT-adatállományból származtatott röntgenképek jelentették, majd a renderelt felszínen alkalmazott szegmentációs technikák létrejöttével az arckoponya csontjai már három dimenzióban is mozgathatóvá váltak, így az úgynevezett virtuális mútéti modellezések is kialakultak. A CAD/CAM technika és a 3D-nyomtatók fejlődésével pedig megjelentek a preoperatívan nyomtatott sínek, lemezek és az úgynevezett kézzel fogható modellmútétek kivitelezései is. A képalkotás fejlődése mindezek által elősegítette a személyre szabott, pontos és megbízhatóbb tervezést, mely jelentősen meghatározza a kezelés sikerességét.
\end{abstract}

Orv Hetil. 2018; 159(39): 1584-1592.

Kulcsszavak: cone-beam CT, cefalometria, CAD/CAM, 3D-nyomtatás

\section{Planning options of reconstructive and orthognathic operation by means of three-dimensional imaging}

We summarize up-to-date planning technics of orthognathic and reconstructive surgery operation which appeared with three-dimensional imaging, using literature data and some clinical examples. In many cases, orthognathic and reconstructive operations mean the only treatment of facial deformity caused by tumour, traumatic injury or congenital anomaly. In this field, radiology plays an important role not only in the diagnosis but also in the planning of the treatment. With the appearance of cone-beam computed tomography (CBCT), the previously used two-dimensional cephalometric analysis on lateral cephalogram was changed for three-dimensional cephalometric measurements. The first step of the adaptation was the lateral and frontal x-ray images generated from the CBCT database and later the volume rendered surface and segmentation technics provided the moving of the facial bones in three dimensions which meant virtual surgical planning. With the development of CAD/CAM technic and the three-dimensional printing, many opportunities became available, such as preoperative bending splints and plates and printed surgical model for the tangible planning. The progress of imaging facilitated the individual, accurate, and reliable planning which significantly determines the success of the treatment.

Keywords: cone-beam computed tomography, cephalometry, CAD/CAM, 3D printing

Dobai A, Markella Zs, Vízkelety T, Barabás J. [Planning options of reconstructive and orthognathic operation by means of three-dimensional imaging]. Orv Hetil. 2018; 159(39): 1584-1592.

(Beérkezett: 2018. április 18.; elfogadva: 2018. június 15.) 


\section{Rövidítések}

$\mathrm{CAD}=$ (computer-aided design) számítógéppel segített tervezés; $\mathrm{CAM}=$ (computer-aided manufacturing) számítógéppel segített gyártás; $\mathrm{CBCT}=$ (cone-beam computed tomography $)$ kúpsugaras számítógépes tomográfia; DICOM = (digital imaging and communications in medicine) digitális képkezelés és kommunikáció az orvostudományban; MIP = (maximal intensity projection) maximális intenzitású pontok vetületi képe; MPR = (multiplanar reconstruction) többsíkú rekonstrukció; $\mathrm{PA}=$ posteroanterior $; \mathrm{VR}=$ volumenrenderelt

Az arcrekonstrukciós és orthognath mütétek gyakran az egyetlen megoldást jelentik a tumor, fejlődési rendellenesség vagy trauma okozta deformitások helyreállítására. A kezelés nélkülözhetetlen eszköze a radiológiai képalkotás, mely nemcsak a diagnosztikában, hanem a kezelés megtervezésében is fontos szerepet játszik.

A mütéti tervezések kezdetben hagyományos röntgenképek, mint például oldalirányú és frontalis teleröntgen, valamint panorámafelvétel segítségével történtek. A teleröntgen technikáját 1913-ban Broadbent és Hofrath egymástól függetlenül írták le [1], majd sorra jelentek meg a különböző cefalometriai analízisek, melyek az arckoponyát alkotó anatómiai struktúrák arányait írták le. Napjainkban a világ leggyakrabban használt analízisei Steiner, Schwarz és Ricketts nevéhez füződnek, azonban Európában a Hasund-analízis terjedt el a leginkább. A teleröntgen-felvétel elkészítése során a páciens fejét standardizált pozícióban rögzítik, ami a késóbbi cefalometriai mérések reprodukálhatósága és összehasonlíthatósága miatt fontos. A röntgenfelvétellel járó nagyítást egy fémskála segítségével korrigálják, melyet a mérések megkezdése előtti kalibrációhoz használnak.

A cefalometriai mérések kivitelezését kezdetben pauszpapírra átrajzolt teleröntgen-felvételen végezték, majd a digitális röntgentechnika 1980. évi megjelenésével elérhetővé váltak a digitális teleröntgenképek és ezzel a cefalometriai referenciapontok szoftveres bejelölése is [2] (1. ábra). A digitális technika által az expozícióhoz szükséges sugárdózis mennyisége csökkent, a cefalometriai pontok azonosítása pontosabbá és gyorsabbá vált, és a kontraszt és a fényerô utólagos változtatásával a képelemzés könnyebbé vált [3].

A röntgenalapú mútéti tervezésnek azonban számos hiányossága van, melyek közül a legfontosabb, hogy a teleröntgenen szummációs képet kapunk a koponyáról. $\mathrm{Az}$ anatómiai képletek egymásra vetülése nemcsak nehezíti, hanem a frontalis irányú teleröntgeneken gyakran lehetetlenné teszi a cefalometriai pontok azonosítását, így például az arcaszimmetria pontos vizsgálatára ezzel a módszerrel nincs lehetőség. Ezt igazolja a posteroanterior (PA) teleröntgen-alapú cefalometriai analízisek száma is, ugyanis a gyakorlatban mindössze a Ricketts által kidolgozott transzverzális analízis terjedt el [4].

Igazi mérföldkőnek a komputertomográf 1973. évi megjelenése számított, mely lehetővé tette az anatómiai képletek háromdimenziós leképezését [5]. A fogászati diagnosztikában ennek a készüléknek egy továbbfejlesztett változata, az úgynevezett cone-beam komputertomográf terjedt el, melynek első típusát, az olasz gyártmányú NewTom 9000-et 1996-ban mutatták be az európai piacon, és az Egyesült Államokban 2001-ben kezdődött meg a forgalmazása [6]. Ettől kezdve a NewTom mellett sorra jelentek meg CBCT-készülékeket gyártó cégek, melyek közül jelenleg a következők a legnagyobb piaci képviselők: Carestream Health (USA), Dentsply Sirona (USA), Imaging Sciences International LLC (USA), J. Morita (Japán), KaVo Dental GmbH (Germany), Planmeca (Finnország), Soredex (Finnország), Vatech (Korea). Az utóbbi években a CBCT-készülékek száma ugrásszerúen megemelkedett mind a kórházak fogászati részlegein, mind a magánpraxisokban, amit egy 2017 ben készült felmérés is alátámaszt, miszerint az Amerikai Egyesült Államokban 800 készüléket adnak el évente [7], azonban az irodalomban európai adatok erre vonatkozóan nem állnak rendelkezésre.

Miután a CBCT megjelenése tette elérhetővé a háromdimenziós mütéti tervezést, a következőkben ezt a képalkotási módszert ismertetjük részleteiben.

\section{Módszer}

\section{Cone-beam komputertomográfos képalkotás}

A CBCT-alapú diagnosztika elsősorban a fogászati szakterületeken terjedt el, ami annak köszönhető, hogy relatíve alacsony sugárdózis mellett képes pontos 3D-képet adni az arckoponya csontszerkezetéról és a fogakról [8].

A sugárdózis jelentősége a szem érintettsége esetében kiemelkedóen fontos, ugyanis a szemlencse sugárérzékenysége magas [9]. Miután egy koponyafelvétel esetében a hagyományos CT sugárdózisa körülbelül tízszer nagyobb, mint a cone-beam volumentomogramé, a fogászati területen és számos fül-orr-gégészeti esetnél is előnyben részesítendő a CBCT alkalmazása a CT-vel szemben [10]. Azonban az 1. táblázat is mutatja [11], hogy ez az eljárás a hagyományos teleröntgenekhez képest jóval nagyobb sugárdózist jelent. Az arcrekonstruk-

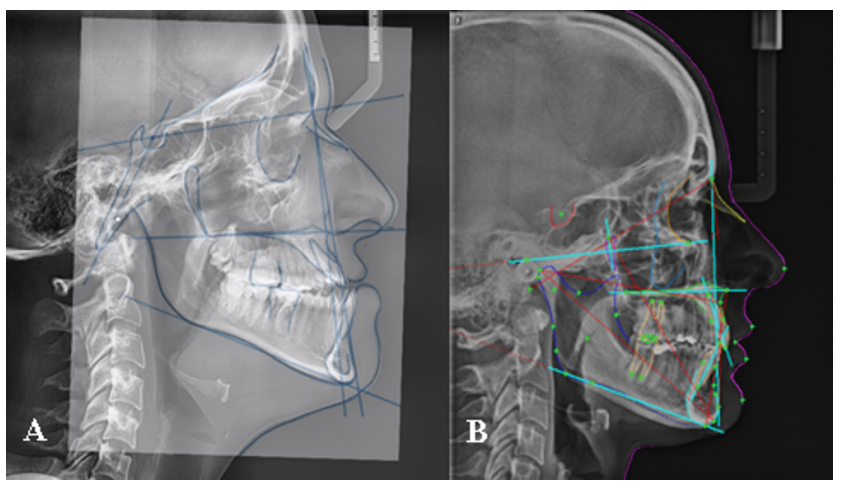

1. ábra

A hagyományos analóg technikával készült röntgenfelvétel $(A)$ és a digitális röntgenkészülékkel létrehozott röntgenképen $(B)$ végzett cefalometriai mérések 
1. táblázat | A fogászati és hagyományos radiológiában elterjedt vizsgálómódszerek effektív sugárdózisai

\begin{tabular}{lc}
\hline Felvételtípus & Effektív dózis $(\mu \mathrm{Sv})$ \\
\hline 1 napi háttérsugárzás & 8 \\
1 posteroanterior teleröntgen & 6 \\
4 ráharapásos intraoralis felvétel & 38 \\
I-CAT CBCT $(6 \times 15,5 \mathrm{~cm} \mathrm{FOV})$ & $32-61$ \\
I-CAT CBCT $(13 \times 15,5 \mathrm{~cm} \mathrm{FOV})$ & $68-133$ \\
Mellkasröntgen & 170 \\
Koponya-CT & 2000 \\
\hline
\end{tabular}

ciós mütétek tervezésekor a koponya háromdimenziós megjelenítése releváns adatokat nyújthat a kezeléshez, emiatt a nagyobb sugárdózis ellenére is az operációk tervezésének fó eszközévé vált. Ezt erősíti az a tény, hogy a nagy volumenü cone-beam volumentomogram felbontása $0,3-0,4 \mathrm{~mm}$, ami nagyobb, mint a 'high-resolution' (nagy felbontású) CT felbontása, így a csontszerkezet pontosabb megítélése biztosított. Fontos megemlíteni, hogy CBCT-felvételeken a fémimplantátumok és egyéb fémek esetében minimális mütermék keletkezik, így lehetővé vált az implantátumok körüli csontállomány precízebb megítélése, amire a CT-készülékkel korábban nem volt lehetőség.

A készülék hátránya, hogy a lágyrészeket nem képes kontrasztosan ábrázolni, így kizárólag a csontok megítélésére alkalmas. Ha figyelembe vesszük, hogy az orthognath és archelyreállító mưtéteknél elsődlegesen a csontokat érintő deformitások, törések jelentik a problémát, a lágyrész egzakt leképezése nélkülözhető. A szkennelés során különböző méretű volumeneket képezhetünk le, melyek mérettartománya a $3 \times 5 \mathrm{~cm}$-tól egészen a $23 \times$ 27 cm-ig terjed; az utóbbinál már a teljes koponyáról háromdimenziós képet kapunk. A felvételek megjeleníthetók a gyártók által biztosított képnézô szoftverekkel, melyek azonban nem alkalmasak arcrekonstrukciós mütétek tervezésére, így ilyen célból a képeket DICOMformátumban exportálhatjuk mütéti tervezőszoftverekbe - közülük a legelterjedtebbek a következők: OnDemand3D ${ }^{\mathrm{TM}}$, Dolphin Imaging, Anatomage, Accuplan, Materialise.

Mindezek alapján elmondható, hogy az utóbbi években a CBCT vált az orthognath és archelyreállító mútétek tervezésének meghatározó eszközévé, így a következő részben a CBCT-adatállományon történő mütéti tervezés lehetőségeit ismertetjük.

\section{Mütéti tervezési lehetőségek}

\section{Tervezés a CBCT-adatállomány 2D-projekciója alapján}

A cefalometriai analízisek a hagyományos teleröntgentechnikán alapulnak, emiatt az anguláris és lineáris mérések normálértékeit is kizárólag ezeken határozták meg.
Ennek következtében az első lépés a 3D-volumentomogram cefalometriai célú használatára az adatállománynak a hagyományos teleröntgen-analízisekben használt síkok szerinti konvertálása volt, melynek során igyekeztek a hagyományos oldalirányú teleröntgenhez hasonló nézetet létrehozni. Így született meg a CBCT-alapú cefalometriai röntgenmegjelenítés, melyen a referenciapontokat a digitális teleröntgenhez hasonlóan lehet bejelölni, és a szoftver automatikusan kiszámolja az általunk kiválasztott analízis értékeit, és a referenciavonalakat és szögeket vonalábrával is szemlélteti a röntgenképen (2. ábra). Több programban, mint például a Dolphin Imagingben is, elérhető a röntgenkép és egy arcfotó egymásra vetítése, miáltal a lágyrész-kontúr elemzése pontosabbá válik (2. ábra).

Számos kutatás hasonlította össze a 2D-teleröntgenen és a CBCT-adatállományból származtatott röntgenmegjelenítésen végzett egyazon méréseket. Annak ellenére, hogy a vizsgálatok közül volt, amelyik statisztikailag szignifikáns eltérést állapított meg [12], többnyire nem találtak klinikailag releváns eltérést a két módszer között $[13,14]$. Ennek következtében a 2D-analíziseket a referenciaértékekkel együtt adaptálták a CBCT-alapú képelemzésekhez. A programokban az oldalirányú röntgenmegjelenítés esetében a maxilla és a mandibula ventrodorsalis irányú eltérései, míg a frontalis nézetben az arcszimmetriák ítélhetők meg. A CBCT-adatállományból létrehozott röntgennézetben már pluszfunkcióként jelent meg, hogy a normától való eltérés figyelembevételével a pontok áthelyezhetők az ideális pozícióba, és a szoftver ezt új vonalábrával szemlélteti. A program két vonalábra egymásra vetítésével mutatja meg, hogy az egyes anatómiai struktúrákat milyen irányba és mennyivel kell elmozdítani.

\section{Tervezés a CBCT-adatállomány 3D-nézeteinek használatával}

A CBCT-felvételek rekonstrukciója során háromdimenziós felületek hozhatók létre, melyek közül a leggyakrabban használt két technika az úgynevezett MIP- (maximal intensity projection) kép és a volumenrenderelt (VR-) modell (3. ábra). A MIP-rekonstrukció során a legnagyobb denzitású pontokat mutatja meg a szoftver, így a csontok megjelenítésére kifejezetten alkalmas. Ennek köszönhetően ez a nézet különösen jelentős a maxillofacialis diagnosztika területén, ugyanis alkalmas törések detektálására és az arckoponya deformitásainak vizsgálatára. A VR-modellek a CBCT-adatállományt három dimenzióban jelenítik meg, és a koponyafelszín az ablakolástól függően számos formában jeleníthető meg, például lágyrész- és csontfelszín-renderelés (3. ábra). Ezen megjelenítési módszerek elérhetők szinte mindegyik tervezőprogramban: OnDemand3D ${ }^{\mathrm{TM}}$, Dolphin Imaging, Anatomage, CranioViewer.

A CBCT-adatállomány alapján a MIP- és a VR-képeken végezhető mütéti tervezések a következők: 


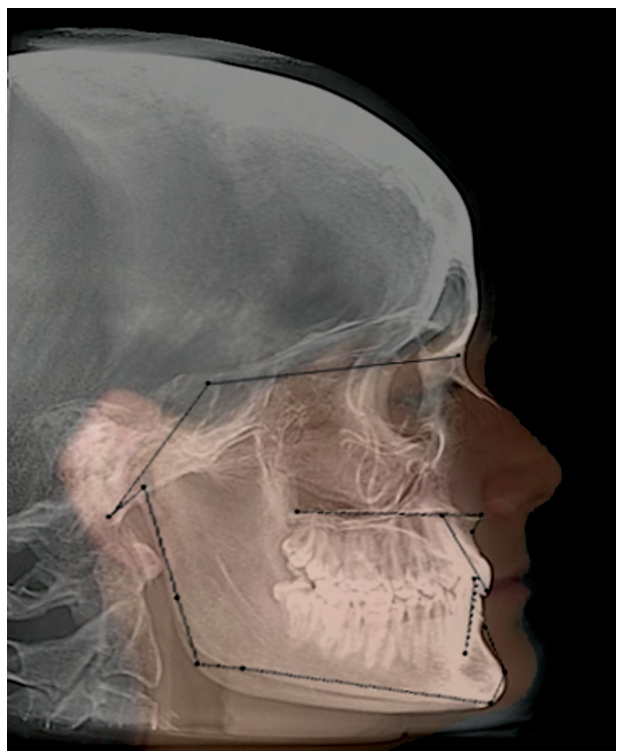

2. ábra

CBCT-adatállományból generált oldalirányú teleröntgen rávetített arcfotóval, valamint cefalometriai mérésekkel

\section{Cefalometriai pontok jelölése}

A referenciapontok bejelölése a MIP- vagy a VR-képeken történik, így a röntgenképekkel szemben itt már lehetőség van a kétoldali pontok detektálására is. Ezzel együtt azonban a 2D cefalometriai pontok definíciói sem elegendôk, és szükség van a pontok háromdimenziós definícióira. Több kutatás is megalkotta a 3D-ben használt fogalmakat, és Ludlow a kutatásában hangsúlyozta, hogy a definíciók pontossága szignifikánsan meghatározza a pontdetektálás megbízhatóságát [15].

A programok - mint például OnDemand3 $\mathrm{D}^{\mathrm{TM}}$, Anatomage, Dolphin Imaging - háromdimenziós koponyát jelenítenek meg, mely forgatható a tér minden irányába, így a kétoldali anatómiai képletek is azonosíthatók. A detektáláskor a legnagyobb probléma a középvonali pontokkal van, hiszen ebben a nézetben felszíni csontok ábrázolódnak jól (4. ábra). Ennek kivitelezésére a legtöbb program a koponyákat szeleteli, így medianosagittalis síkban elfelezett koponyát hoz létre.

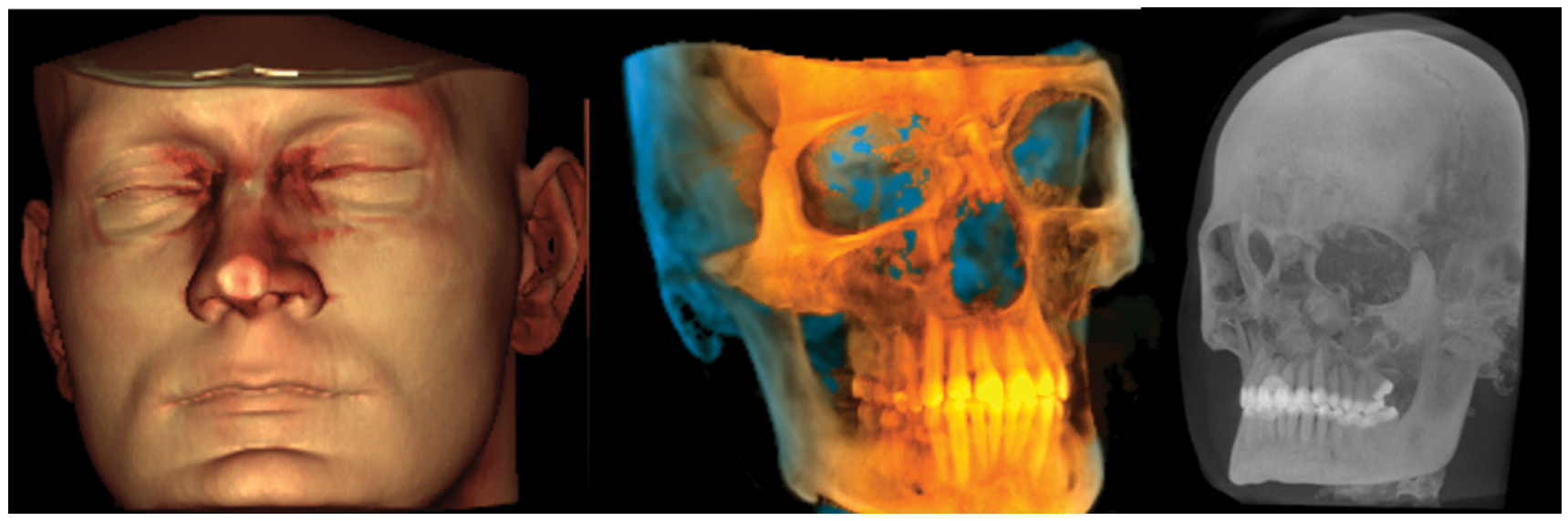

3. ábra $\mid$ CBCT-adatállomány volumenrenderelt megjelenítési módjai

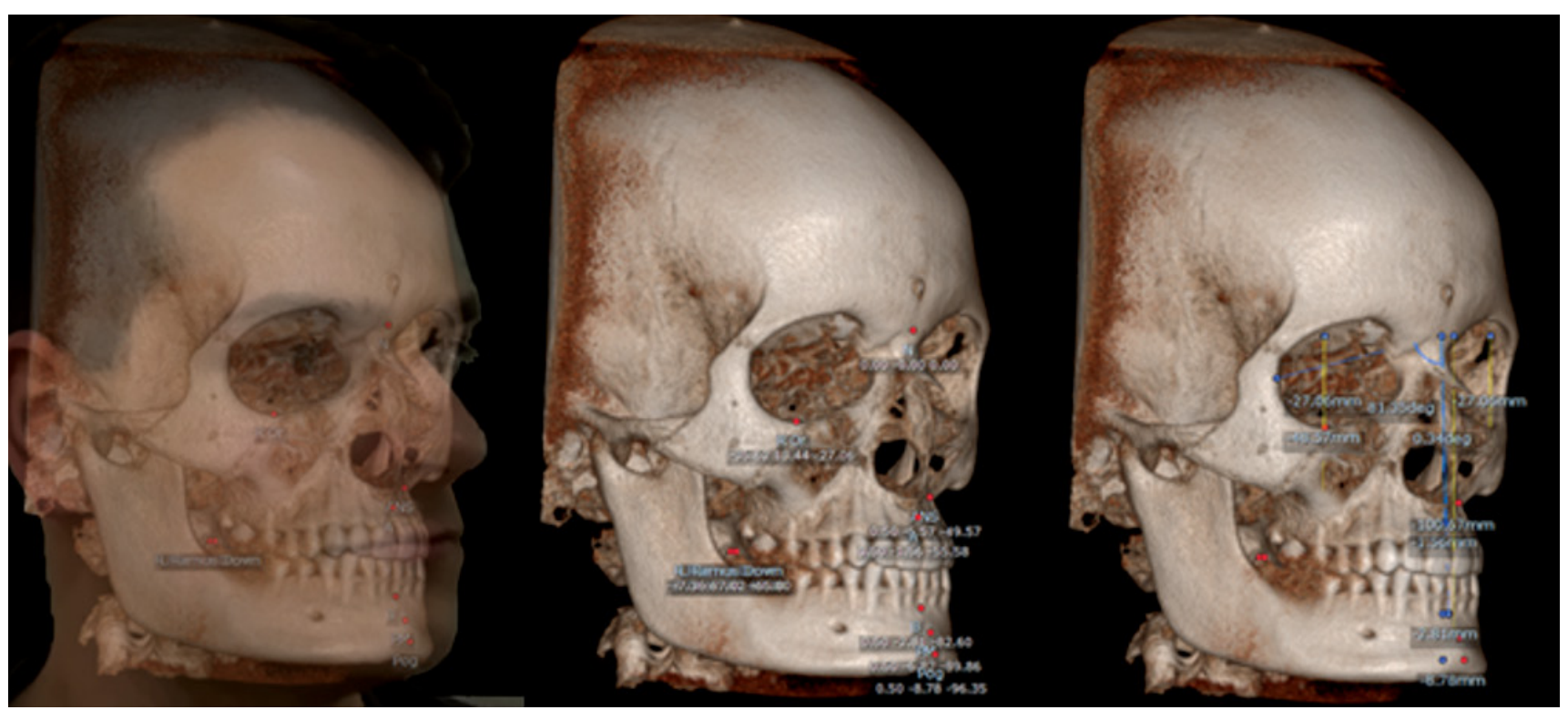

4. ábra

3D cefalometriai mérések volumenrenderelt felszínen 


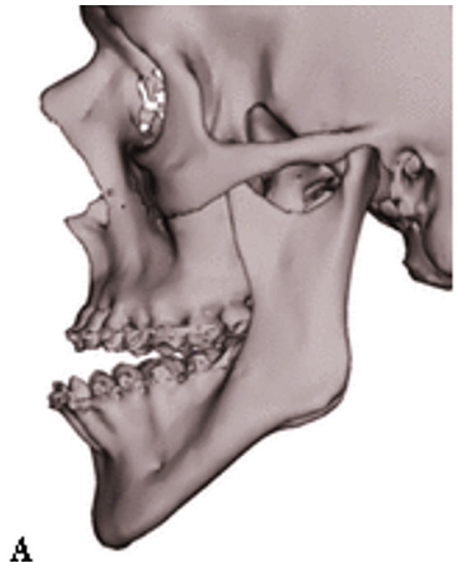

B
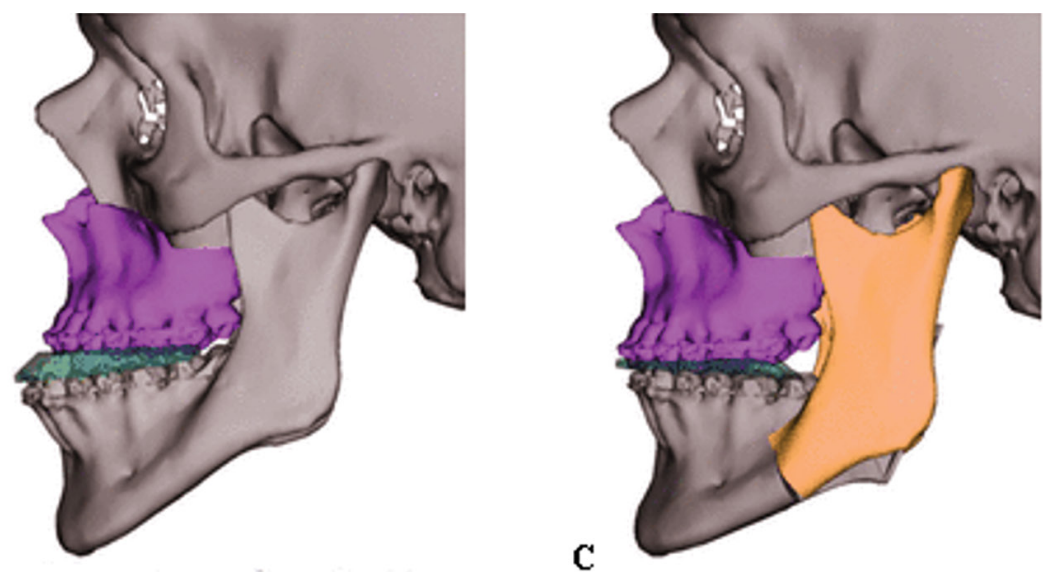

5. ábra | Virtuális sebészeti tervezés során alkalmazott állcsont-szegmentáció. Az $A$ ábra a kiindulás, a $B$ és a $C$ ábra a szegmentáció lépéseit mutatja

A MIP- és a VR-képeken a leképezésboól adódóan a cefalometriai pontok bejelölése kevésbé megbízható, mint a hagyományos CT-megjelenítést szolgáló MPR(multiplanar reconstruction) nézetben [16], így a szoftverfejlesztôk a cefalometriai célú MIP-nézetet kiegészítették az MPR-megjelenítéssel. Ezáltal a coronalis, sagittalis és axialis síkú CBCT-szeleteken a pontokat precízen és reprodukálhatóan lehet bejelölni, míg a MIPnézet lehetôvé teszi az anatómiai képletek viszonyának könnyebb értelmezését.

A cefalometriai méréseket a legtöbb szoftver, mint például az OnDemand3D ${ }^{\mathrm{TM}}$, Dolphin Imaging, Anatomage, CranioViewer azáltal számolja ki, hogy a pontokat egy előre beállított arcközépsíkra és erre merőleges coronalis síkra vetíti, és a $2 \mathrm{D}$-képeken végzi el a méréseket; így megvalósítható az, hogy alkalmazzuk a hagyományos 2D-technikán alapuló analíziseket, ugyanakkor a 3D segítségével további modellezési folyamatok is elérhetők.

\section{Szegmentációalapú tervezés}

A háromdimenziójú, forgatható MIP- és VR-képek alkalmasak a koponya térbeli vizsgálatára és az egyes anatómiai képletek szegmentálására. Ezzel a módszerrel az anatómiai struktúrákat el lehet választani egymástól, és kirakóként lehet modellezni a koponyát. A rekonstruktív mútétek során a leggyakrabban a maxilla, a mandibulabasis és a felhágóágak szegmentálása szükséges az ideális arckoponyaviszonyok helyreállításához. Miután a szegmenteket az ideális pozícióba helyezzük, számos szoftver, mint például az Accuplan és a Materialise, meghatározza a korábban bejelölt cefalometriai pontokból a kiindulási és a végállapot közötti eltérés mértékét és irányát (5. ábra). Ezek a funkciók relevánsak a mútét tervezése során, hiszen mind a vizuálisan 3D-megjelenítés, mind a normától való eltérés kiszámítása jelentősen megkönnyíti a sebészek számára a mútét kivitelezését.

\section{Tükrözés használata a tervezés során}

A craniofacialis deformitások közül a hagyományos 2Dcefalometriával az arcaszimmetriát okozó elváltozások pontos diagnosztikája csaknem lehetetlen volt. A fronta- lis teleröntgenen az anatómiai képletek szummációja miatt a pontok helyzete sok esetben bizonytalan volt, így a CBCT igazi fordulópontnak számít az aszimmetria diagnosztikájában. Abban az esetben, ha a páciens rendelkezik ép arcféllel, a legegyszerúbb módszer a mútéti tervezéshez az ép oldal tükrözése. A 6. ábra szemlélteti a módszer alkalmazását szemüreg-rekonstrukció tervezésekor, melynek során az ép oldalt tükrözik a sérült oldalra, és a tükrözött és ép referenciapontok közötti távolságok segítik a mútéti modellezést.

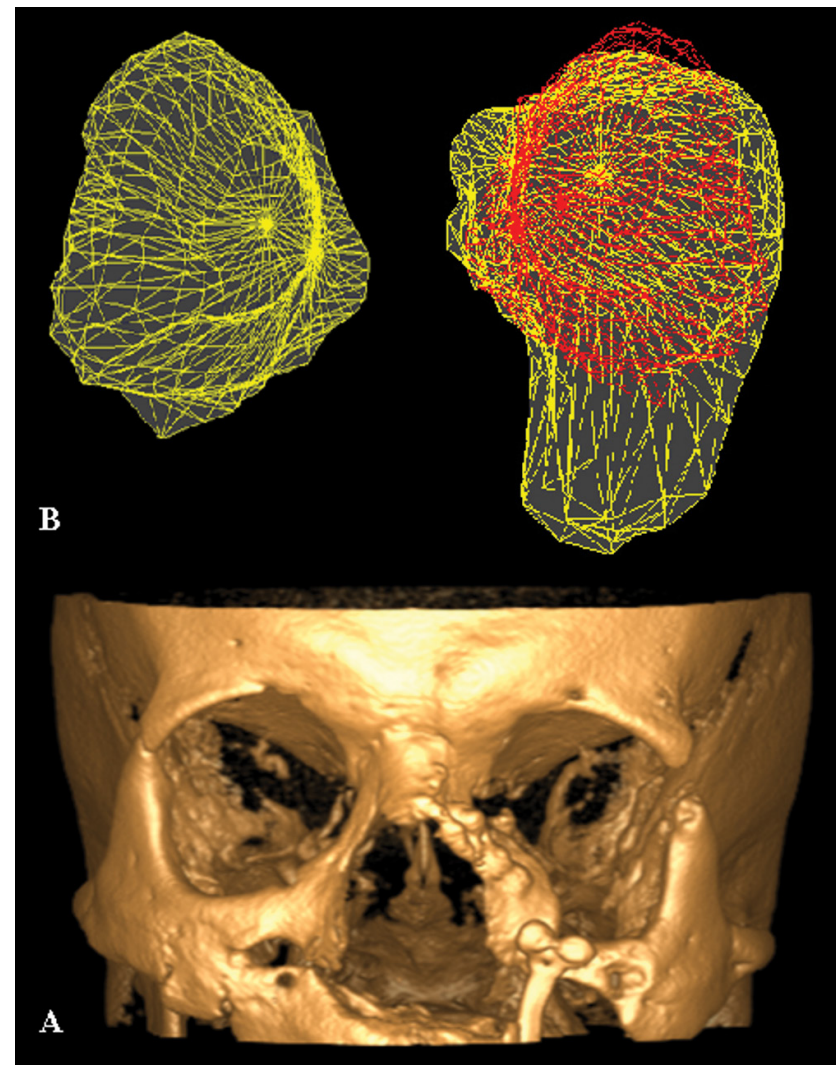

6. ábra $\quad$ Az orbitarekonstrukció során alkalmazott tükrözéses módszer. Az $A$ ábra a trauma okozta orbitaaszimmetriát mutatja volumenrenderelt felszín segítségével, a $B$ ábra a három dimenzióban meghatározott szemüregeket (sárga vonal) és az ép oldal tükrözését szemlélteti (piros vonal) 


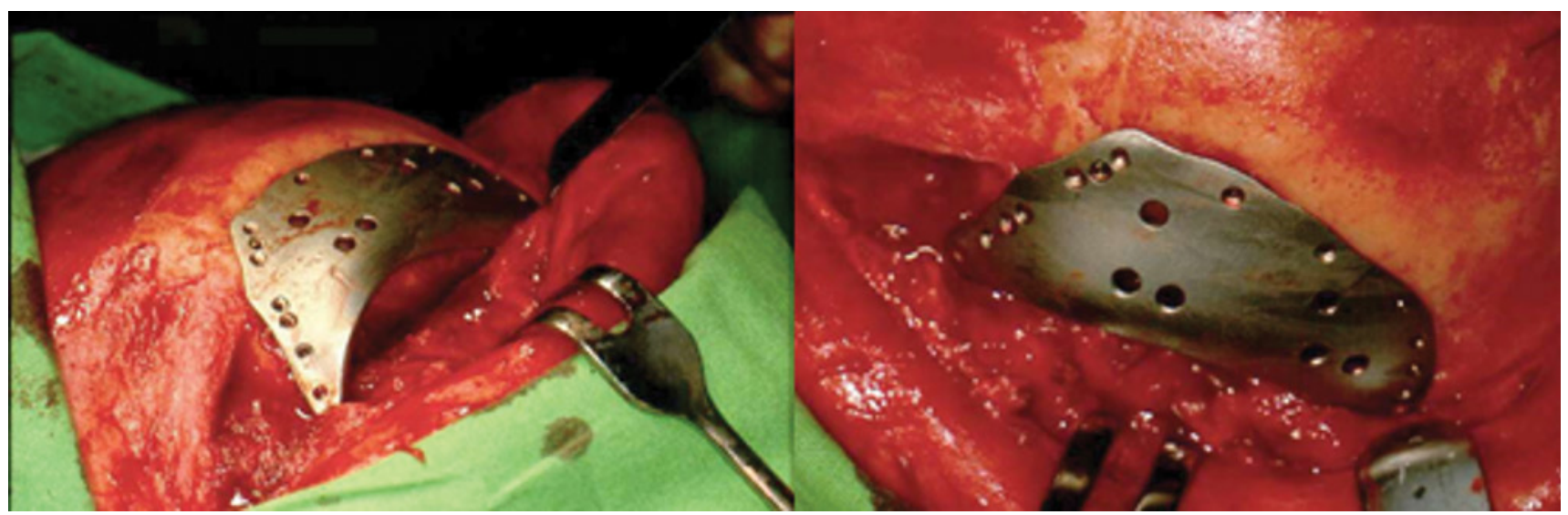

7. ábra | Orbitarekonstrukció során alkalmazott 3D-nyomtatással készült titánlemez behelyezése a szemüregbe

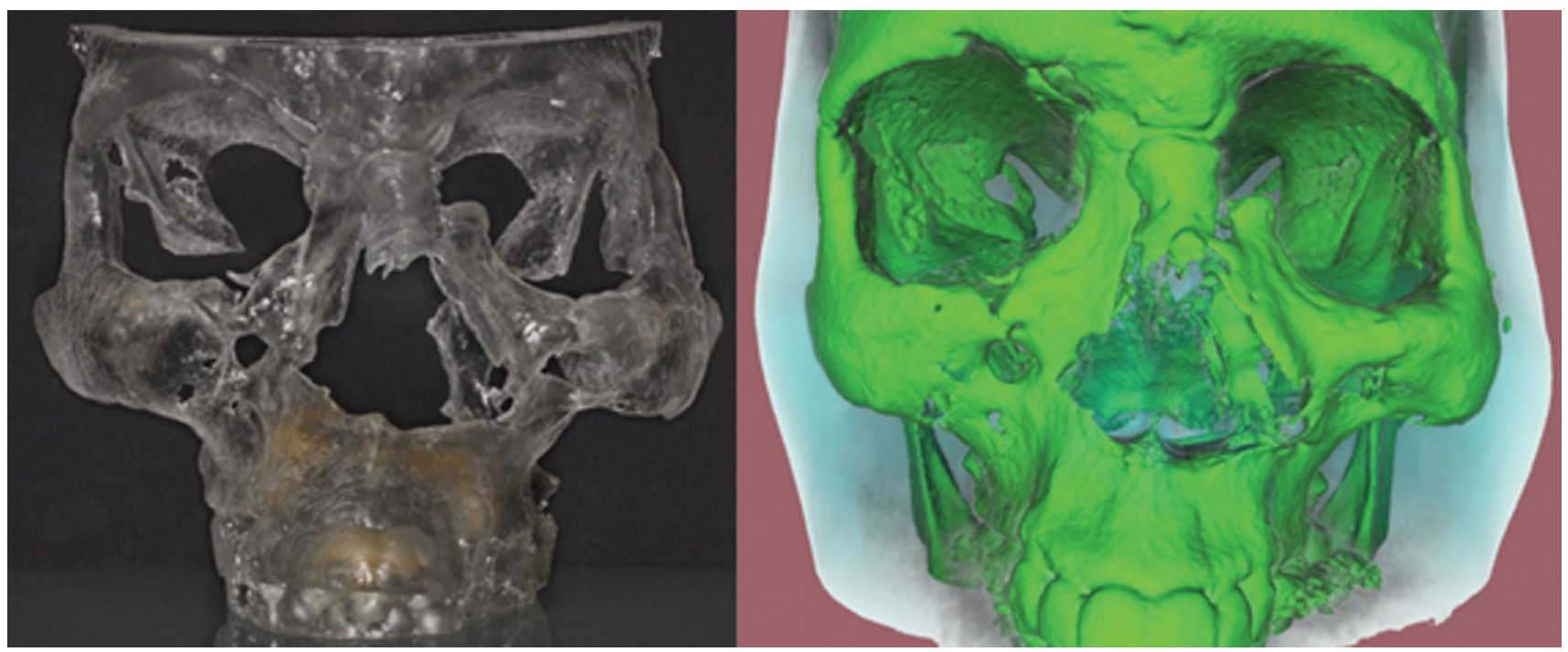

8. ábra $\quad$ 3D-nyomtatóval készített mútéti modell

4. 3D-nyomtató és CAD/CAM technika alkalmazása A CAD (computer-aided design), azaz a számítógép segítségével végzett tervezés a CAD/CAM rendszer szoftveres része: az orthognath mútétek tervezésekor a program szenzorokkal letapogatott gipszmintáról digitális mintát készít, majd a CBCT-adatállomány és esetlegesen egy beszkennelt arc adatainak fúziójával különböző műtéti segédeszközök, például rögzítősínek, alloplasztikus csontimplantátumok, mütéti koponyamodellek tervezhetők. A CAM- (computer-aided manufacturing) technika által a komputer segítségével sztereolitográf, 3Dnyomtató vagy frézgép készíti el a megtervezett formát.

A CAD/CAM technika és a 3D-nyomtatás fejlődése új kaput nyitott a helyreállító operációk tervezésében, így manapság a CBCT-adatállomány alapján kinyomtatott formáknak számos felhasználási módja terjedt el:

- Okklúziós sínek: az orthognath mútéteknél megjelentek a kinyomtatott okklúziós rögzítők [17, 18], melyek a hagyományos módszerrel készült rögzítőkhöz képest pontosabb és megbízhatóbb illeszkedést biztosítanak [19], és az alsó arc deviációjának korrekciójánál kiemelt jelentőségük van [20].
- Fixációs lemezek: a technika fejlődésével lehetővé vált a fixációs lemezek nyomtatása is, melyek precíz pozicionálást és rögzítést biztosítanak például a Le Fort I. osteotomia során [21] vagy akár szemüregmútét alatt. - Alloplasztikus csontimplantátumok: a különböző alloplasztikus anyagoknak (poli[éter-éter-keton], titán, valamint titán és akrilcement keveréke) [22] köszönhetően lehetővé vált az arc és az agykoponya csontjainak pótlása CAD/CAM technikával, melynek klinikai alkalmazását az irodalomban több cikk is bemutatja. Így például Zhao és mtsai a járomcsont helyére terveztek és ültettek be alloplasztikus implantátumot [23], míg Sunderland és mtsai a homlokcsont egy részét előre formázott titánhálóval egészítették ki, melynek tervezését specifikusan az egyénre szabták [24]. A 7. ábrán egy orbitarekonstrukció céljából CBCT-adatállomány alapján CAD/CAM technikával tervezett és kinyomtatott titánlemez mütéti behelyezése látható.

- 3D-modell: a kinyomtatott 3D-modell által nemcsak virtuálisan, hanem kézzel foghatóan is meg lehet tervezni a mútétet (8. ábra), valamint lehetővé teszi a rögzítőlemezek meghajlítását a mútét előtt annak ér- 


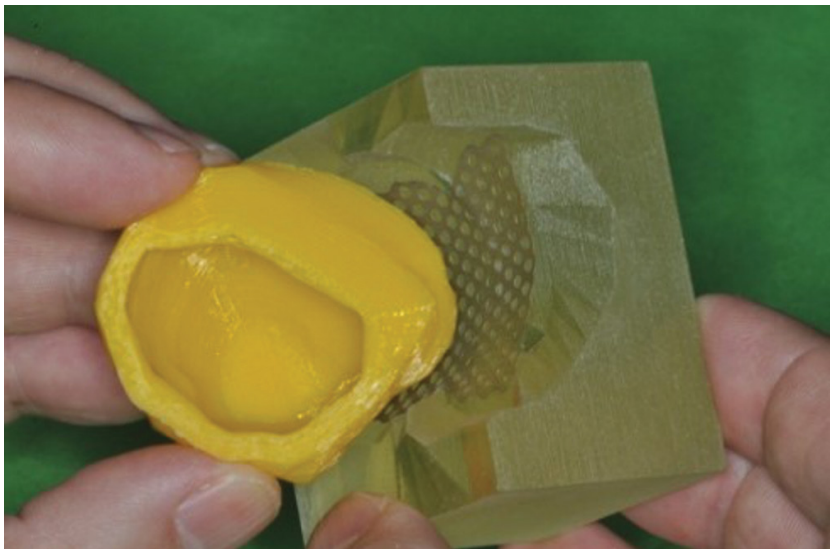

9. ábra

3D-nyomtatóval készült szemüreg és a preoperatív szakaszban meghajlított titánlemez

dekében, hogy az illeszkedés minél tökéletesebb legyen a csont felszínén [19]. Ennek gyakorlati alkalmazását szemlélteti a 9. ábra, mely egy orbita-helyreállító mütét tervezéséhez használt 3D-modellt mutat. Az ép szemüreg tükrözése során keletkezett forma és a sérült szemüreg negatívjának kinyomtatásával még a preoperatív szakaszban történt a fémháló formára hajlítása.

\section{Eredmények}

A következőkben a fentiekben ismertetett CBCT-alapú tervezés gyakorlati alkalmazását egy egyszerű példán keresztül szemléltetjük.

Egy 20 éves páciens arcaszimmetria és az ebből fakadó okklúziós rendellenesség miatt került az Arc-, Állcsont-, Szájsebészeti és Fogászati Klinikára. A diagnózis pontos felállításához CBCT-felvétel készült, melyet DICOMformátumban az általunk használt CranioViewer szoftverbe exportáltunk. A cefalometriai pontokat az MPRés a MIP-nézetben a tér mindhárom irányában detektáltuk, majd az arckoponyát úgynevezett vonalábra formájában ábrázoltuk (10. ábra). Első lépésként meghatároztuk a mandibula aszimmetriájának mértékét azáltal, hogy figyelembe vettük a kétoldali cefalometriai pon-

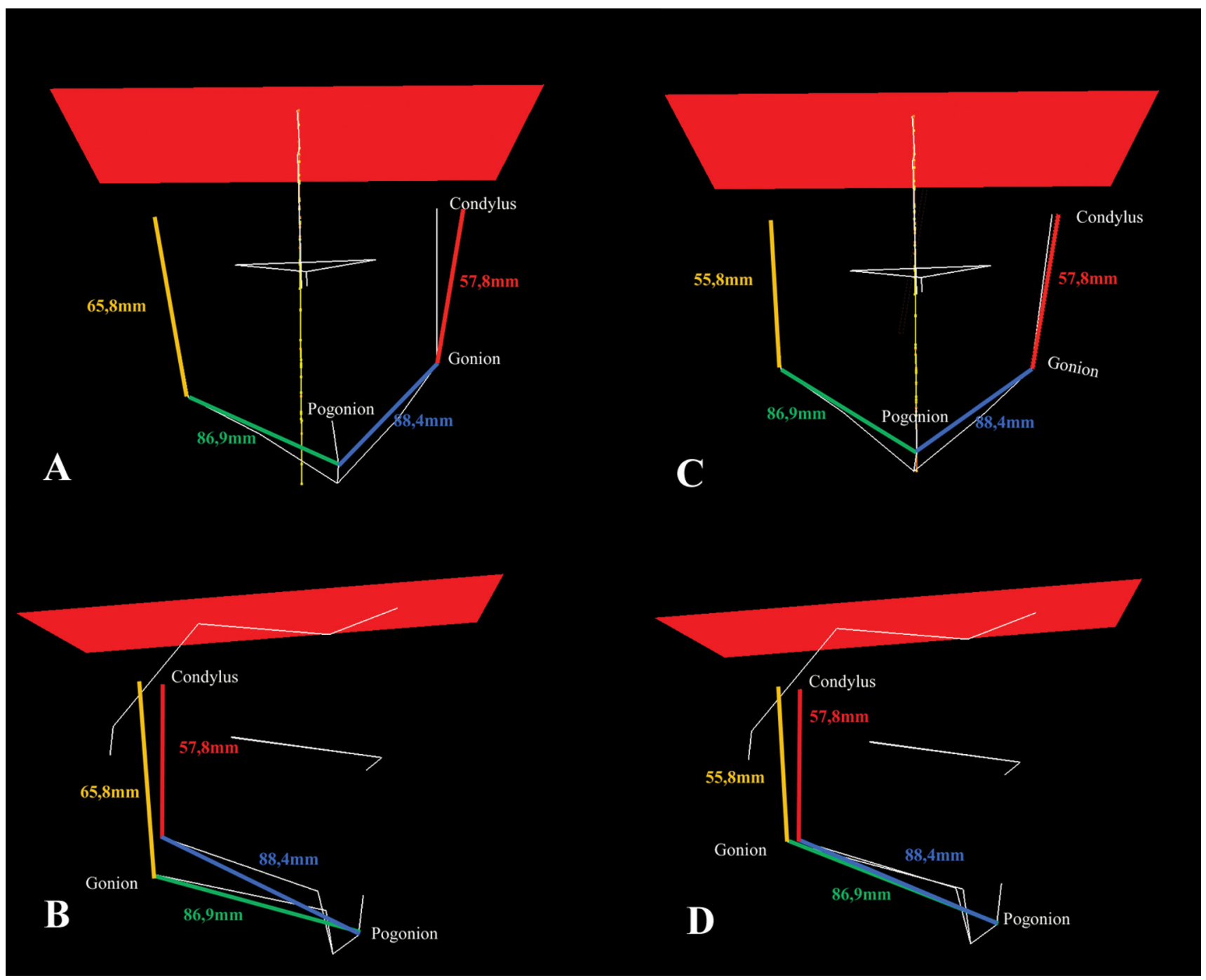

10. ábra

A CBCT-adatállományon detektált cefalometriai pontokból létrehozott vonalábrák. Az $A$ és a $B$ kép a preoperatív állapotot, a $C$ és a $D$ ábra a posztoperatív állapotot mutatja frontalis és lateralis nézetben 
tok arcközépsíkhoz viszonyított helyzetét (10. ábra). Ezzel egyben definiáltuk az elérendő célt, azaz hogy a deviáló állcsúcs az arc középsíkjába kerüljön, és így az szimmetrikussá váljon. A szoftver által az alsó állcsont négy szakaszra bontható; a szakaszok hossza változtatható, és a fragmentumok követik a szomszédos szakasz elmozdulását. Ez a megoldás lehetővé teszi, hogy a fragmentumok változtatásával különbözőképpen, a jelen esetben például a bal mandibulatest hosszának növelésével vagy a jobb mandibulatest rövidítésével érjük el az ideális pozíciót. Annak megítélésére, hogy melyik variáció nyújtja az optimális eredményt, létre kell hozni egy arcközépsíkra vetített úgynevezett kétdimenziós cefalogramot: ezáltal a jobb és a bal oldalon külön-külön végzett cefalometriai analízis alapján megmondható, hogy melyik tér el jobban az adott egyénnél kiszámolt ideális értéktól. Figyelembe véve ezt, a tervezés során a jobb mandibulatest és ramus hosszát rövidítettük, és a mentum az arcközépvonalba került (10. ábra), aminek köszönhetően az okklúzió is normalizálódott.

\section{Következtetések}

$\mathrm{Az}$ arcrekonstrukciós műtétek tervezéséhez rutinszerüen használt teleröntgen-felvételek szerepét az első conebeam CT megjelenése óta fokozatosan a háromdimenziós volumentomogramok veszik át, ami az arckoponya háromdimenziós, torzítás- és nagyításmentes leképezésének köszönhető [25]. A teleröntgen-alapú kezeléstervezés során alkalmazott cefalometriai analíziseket kezdetben a CBCT-adatállományból létrehozott röntgenszerű nézetre ültették át, majd elérhetővé váltak a tényleges 3D-adatállományon - a MPR-, MIP- vagy VRnézetben - végezhető tervezési módszerek is. Ezen módszerek az arcaszimmetria detektálása mellett lehetővé tették a megbízható és reprodukálható mérések kivitelezését és a csontok szegmentálásával a mútétek virtuális modellezését is. Ennek folytatásaként a CAD/CAM technika és a 3D-nyomtatók fejlődésével megjelent a páciensre szabott és preoperatívan formázott mútéti eszközök gyártása, valamint a 3D-modellek kinyomtatásával a kézzel fogható modellmútét kivitelezése is. Az irodalomban néhány tanulmány vizsgálta a CBCT-alapú mütéti tervezés előnyeit, összevetve azokat a konvencionális mütéti tervezéssel. Resnick és mtsai 2016-ban [26], Steinhuber és mtsai 2017-ben igazolták, hogy a virtuális mütéti tervezés szignifikánsan kevesebb időt jelent az orvos számára, mint a hagyományos eljárás, továbbá kevesebb költséggel jár [27]. Egy 2017-ben publikált svéd tanulmány a virtuális mütéti tervezésről alkotott véleményeket mérte fel kérdőív segítségével. A kutatásban a svéd oromaxillofacialis és sztomatológiai intézetek 94\%-a vett részt, és a megkérdezettek mindössze $8 \%$-a preferálta a hagyományos tervezési eljárásokat a virtuális sebészeti tervezéssel szemben. A válaszadók 77\%-a tapasztalta azt, hogy a virtuális modellezés precízebb kezelést tesz lehetővé, és $62 \%$-uk szerint a mütét elötti tájékoztatást is megkönnyíti [28].

Mindezek alapján elmondható, hogy a cone-beam CT által új lehetőségek nyíltak meg az orthognath és arcrekonstrukciós mütétek tervezésében, melyek mind a páciens, mind az orvos számára számos előnyt nyújtanak, így szerepük a jövő sebészetében meghatározó lehet.

Anyagi támogatás: A közlemény megírása, illetve a kapcsolódó kutatómunka anyagi támogatásban nem részesült.

Szerzôi munkamegosztás: M. Zs. a szoftverek müködési leírását végezte. B. J. a cikk arc-, állcsont- és szájsebészeti anyagát biztosította, valamint V. T.-vel a gyakorlati tapasztalatok megosztásával és a cefalometriai mérések kivitelezésének ismertetésével járult hozzá a cikk megírásához. D. A. az irodalomkutatást és a cikk megírását végezte.

Érdekeltségek: A szerzőknek nincsenek érdekeltségeik.

\section{Irodalom}

[1] Sági I, Budai M. History of orthodontics. [Az orthodontia története.] Kaleidoscope 2016; 7: 516-528. [Hungarian]

[2] Moore R. Computed radiography. Med Electron. 1980; 11: 78-79.

[3] Näslund EB, Kruger M, Petersson A, et al. Analysis of low-dose digital lateral cephalometric radiographs. Dentomaxillofac Radiol. 1998; 27: 136-139.

[4] Ricketts RM. Rocky Mountain Data Systems. Orthodontic diagnosis and planning: their roles in preventive and rehabilitative dentistry. Rocky Mountain/Orthodontics, Denver, 1982.

[5] Hounsfield GN. Computerized transverse axial scanning (tomography). 1. Description of system. Br J Radiol. 1973; 46: 1016-1022.

[6] Hatcher DC. Operational principles for cone-beam computed tomography. J Am Dent Assoc. 2010; 141(Suppl): 3S-6S.

[7] Global CBCT dental imaging market is expected to reach USD 817.5 million by 2023 with a CAGR of $9.8 \%$. Available from: https://www.prnewswire.com/news-releases/global-cbct-dental-imaging-market-is-expected-to-reach-usd-8175-millionby-2023-with-a-cagr-of-98-300444090.html [accessed: Market Research Future April 24, 2017].

[8] Schreindorfer K, Kiss A, Marada G. Maxillary sinusitis as a diag nostical adverse finding of the dental cone-beam computed tomography study. [Sinusitis maxillaris mint a fogászati cone-beam komputertomográfiás vizsgálat melléklelete.] Orv Hetil. 2017; 158: 1747-1753. [Hungarian]

[9] Barnard SG, Ainsbury EA, Quinlan RA, et al. Radiation protection of the eye lens in medical workers - basis and impact of the ICRP recommendations. Br J Radiol. 2016; 89: 20151034

[10] Perényi Á, Bella Z, Baráth Z, et al. Role of cone-beam computed tomography in diagnostic otorhinolaryngological imaging. [A cone-beam komputertomográfia alkalmazása a fül-orr-gégészeti képalkotásban.] Orv Hetil. 2016; 157: 52-58. [Hungarian]

[11] Ludlow JB, Davies-Ludlow LE, Brooks SL, et al. Dosimetry of 3 CBCT devices for oral and maxillofacial radiology: CB Mercuray, NewTom 3G and i-CAT. Dentomaxillofac Radiol. 2006; 35: 219-226. 
[12] Gribel BF, Gribel MN, Frazäo DC, et al. Accuracy and reliability of craniometric measurements on lateral cephalometry and 3D measurements on CBCT scans. Angle Orthod. 2011; 81: 26-35.

[13] Kumar V, Ludlow JB, Mol A, et al. Comparison of conventional and cone beam CT synthesized cephalograms. Dentomaxillofac Radiol. 2007; 36: 263-269.

[14] Park CS, Park JK, Kim H, et al. Comparison of conventional lateral cephalograms with corresponding CBCT radiographs. Imaging Sci Dent. 2012; 42: 201-205.

[15] Ludlow JB, Gubler M, Cevidanes L, et al. Precision of cephalometric landmark identification: cone-beam computed tomography vs conventional cephalometric views. Am J Orthod Dentofacial Orthop. 2009; 136: 312.el-312.el0.

[16] Fernandes TM, Adamczyk J, Poleti ML, et al. Comparison between $3 \mathrm{D}$ volumetric rendering and multiplanar slices on the reliability of linear measurements on CBCT images: an in vitro study. J Appl Oral Sci. 2015; 23: 56-63.

[17] Scolozzi P. Computer-aided design and computer-aided modeling $(\mathrm{CAD} / \mathrm{CAM})$ generated surgical splints, cutting guides and custom-made implants: which indications in orthognathic surgery? Rev Stomatol Chir Maxillofac Chir Orale 2015; 116: 343349.

[18] Vale F, Scherzberg J, Cavaleiro J, et al. 3D virtual planning in orthognathic surgery and CAD/CAM surgical splints generation in one patient with craniofacial microsomia: a case report. Dental Press J Orthod. 2016; 21: 89-100.

[19] Lin HH, Lonic D, Lo LJ. 3D printing in orthognathic surgery - a literature review. J Formos Med Assoc. 2018; 117: 547-558.

[20] Seres L, Varga E Jr, Kocsis A, et al. Correction of a severe facial asymmetry with computerized planning and with the use of a rapid prototyped surgical template: a case report/technique article. Head Face Med. 2014; 10: 27.

[21] Huang SF, Lo LJ, Lin CL. Biomechanical optimization of a custom-made positioning and fixing bone plate for Le Fort I oste- otomy by finite element analysis. Comput Biol Med. 2016; 68: $49-56$.

[22] Ng ZY, Ang WJ, Nawaz I. Computer-designed polyetheretherketone implants versus titanium mesh ( \pm acrylic cement) in alloplastic cranioplasty: a retrospective single-surgeon, single-center study. J Craniofac Surg. 2014; 25: el85-el89.

[23] Zhao L, Patel PK, Cohen M. Application of virtual surgical planning with computer assisted design and manufacturing technology to cranio-maxillofacial surgery. Arch Plast Surg. 2012; 39: 309-316.

[24] Sunderland IR, Edwards G, Mainprize J, et al. A technique for intraoperative creation of patient-specific titanium mesh implants. Plast Surg. 2015; 23: 95-99.

[25] Papadopoulos MA, Jannowitz C, Boettcher P, et al. Three-dimensional fetal cephalometry: an evaluation of the reliability of cephalometric measurements based on three-dimensional CT reconstructions and on dry skulls of sheep fetuses. J Craniomaxillofac Surg. 2005; 33: 229-237.

[26] Resnick CM, Inverso G, Wrzosek M, et al. Is there a difference in cost between standard and virtual surgical planning for orthognathic surgery? J Oral Maxillofac Surg. 2016; 74: 1827-1833.

[27] Steinhuber T, Brunold S, Gärtner C, et al. Is virtual surgical planning in orthognathic surgery faster than conventional planning? A time and workflow analysis of an office-based workflow for single- and double-jaw surgery. J Oral Maxillofac Surg. 2018; 76: 397-407. [Epub 2017Jul 25]

[28] Al-Dory H, Bergström M. Virtual surgical planning in orthognathic surgery, mandibular reconstruction, and dental implant treatment. Umeå University, 2017.

(Dobai Adrienn dr., Nyíregyháza, Kéz utca 19., 4400 e-mail: adrienn.dobai@gmail.com)

\section{"Quam quisque norit artem, in hac se exerceat." (Cicero) (Ki-ki azt a mesterséget folytassa, amit kitanult.)}

A cikk a Creative Commons Attribution-NonCommercial 4.0 International License (https://creativecommons.org/licenses/by-nc/4.0) feltételei szerint publikált Open Access közlemény, melynek szellemében a cikk nem kereskedelmi célból bármilyen médiumban szabadon felhasználható, megosztható és újraközölhető, feltéve, hogy az eredeti szerző és a közlés helye, illetve a CC License linkje és az esetlegesen végrehajtott módositások feltüntetésre kerülnek. 